\title{
Structural Green Supply Chain Management Mechanism of Export-Based Manufacturing Firms in Korea
}

\author{
Donghyuk Jo ${ }^{1}$ and Yonghee Kim ${ }^{2, *}$ \\ 1 Department of Business Administration, Soongsil University, Seoul, Korea; joe@ssu.ac.kr \\ 2 Department of Business Administration, Soongsil University, Seoul, Korea; yh.kim@soongsil.ac.kr \\ * Correspondence: yh.kim@soongsil.ac.kr
}

\begin{abstract}
Today's export-based manufacturers face the need to implement green supply chains more efficiently in order to overcome environmental barriers in increasingly competitive export markets and to improve export performance. This study examines the structural relationship between environmental collaboration, green innovation capacity, and performance based on the findings of previous studies in order to identify the factors affecting the green supply chain management (GSCM) performance of Korean export-based manufacturers. The study finds that environmental collaboration in the green supply chain environment is an important driver of green innovation capacity for export-based Korean manufacturers. It also finds that green innovation capacity has a positive effect on export performance through environmental performance. This study establishes a theoretical basis for the systematic study of the structural mechanisms of green supply chains and suggests strategic directions for export-based manufacturing firms' successful GSCM implementation.
\end{abstract}

Keywords: Sustainability, SMEs, Supply Chain Collaboration, Supply Chain Visibility, Supply Chain Agility

\section{Introduction}

Both international environmental conventions and environmental regulations are being strengthened in line with changes in the global environment as a way to reduce greenhouse gas emissions and environmental pollution. It is becoming increasingly important to address environmental issues in order to foster sustainable management $[1,2]$. In these circumstances, export manufacturers are finding it impossible to meet the increasing environmental demands on their own. Facilitating environmental collaboration by establishing a green supply chain is proving an effective countermeasure [3,4].

However, small Korean export manufacturers are finding it difficult to efficiently conduct environmental management or construct environment green supply chains, for a variety of reasons. First, converting directly to a green supply chain system is costly. Second, the current level of environmental awareness is inadequate. Third, even firms that have an environmental management system may lack practical evidence about how they can benefit from it [5].

The research on supply chains indicates that environmental issues will be important for manufacturers in Asia over the next few decades. Most Korean firms strive to implement GSCM or integrated environmental management because of external pressures such as environmental concerns and regulations or green growth policies. For example, Korea's R\&D policy focuses on green growth, and international regulations governing environmental protection such as the Restriction of Hazardous Substances Directive (RoHS) and the Waste Electrical and Electronic Equipment (WEEE) encourage governments and businesses to establish environmental strategies and implement GSCM [2]. Thus, Korea's export manufacturers are experiencing an increasing need 
to build green supply chains more efficiently in order to overcome the environmental barriers they face in export markets and improve their export performance [5].

In today's business environment, which requires the pursuit of both economic and environmental performance, conducting GSCM activities is considered a very important success factor in firms' continuous growth and development [6]. The practice of GSCM is based on the literature on environmental management and SCM. GSCM involves adding a "green" dimension (i.e., environmental factors) to supply chain management (SCM) in order to deal with the relationship between SCM and the natural environment, as well as the influence of those two factors [7]. GSCM not only promotes collaboration, efficiency, and synergy among business partners, but also helps to increase firms' environmental performance, minimize their waste, and reduce their costs [4]. To achieve sustainable development, firms must redesign their products and adopt new technologies for processes, even if the business model of SCM changes [8]. Many researchers have striven to understand the strategic implications of GSCM [9].

GSCM has recently evolved as a process involving the internal organization and management of partner firms in upstream and downstream supply chains, which can minimize the overall environmental impacts of forward and reverse flows [10]. SCM activities cannot contribute to the effective integration of the entire supply chain if conducted independently. Suppliers, manufacturers, and customers must be integrated in order to implement GSCM practices. Nevertheless, previous studies on environmental initiatives have focused on selected functional areas [11]. Fully understanding GSCM requires that we focus on supply chain processes from upstream and downstream. Achieving sustainable organizational performance requires the integration of cross-functional integration within the enterprise and an implementation of environmental management practices with suppliers or customers [10]. In the GSCM context, internal environmental collaboration is defined as the implementation of environmental management practices within a manufacturing firm. To eliminate stakeholder concerns about environmental issues, manufacturers have adopted a variety of strategies focusing on internal GSCM, such as environmental management systems (EMS) and certification (e.g., ISO14000/ISO14001 accreditation) and cross-functional collaboration for environmental improvement [11,12]. External environmental collaboration in the GSCM context is the process wherein organizations and customers jointly plan GSCM initiatives and environmental management practices. For manufacturers, external environmental collaboration requires varying degrees of integration with supply chain partners, such as upstream integration with suppliers and downstream integration with customers [2,11].

Green management requires a consideration of how green practices affect the company's competitiveness and profitability. As consumers' environmental concerns increase, green innovation and environmental innovation can be seen as a business opportunity. Advanced firms are pursuing GSCM sustainable competition strategies by using the environmental improvement of green logistics and supply chains as a strategic weapon, and are striving to meet environmental goals through green management innovation such as green product and green process innovation [13,14].

Although research interest in green innovation (as opposed to traditional innovation) has increased over the past few years, research on green innovation is still new. While traditional innovation involves the development of new products, materials, processes, services, or organizational forms to gain competitive advantage, green innovation is the development of a new idea, good, service, process, or management that can be used to deal with environmental problems [15].

Green innovation modifies both green product design and existing product design to reduce negative impacts on the environment at all stages of the product's life cycle. Green innovation uses strategies to mitigate or recapture the environmental impacts of pollution-producers or resource users, or to reduce resource use by anticipating adverse environmental impacts. Manufacturers can develop green innovations to address environmental concerns among stakeholders and reduce the environmental impacts of their production and service activities [13]. Manufacturing firms can also reduce their production costs and improve their economic efficiency by following environmental 
practices such as reducing energy consumption, reusing materials, and redefining operations and production processes. In other words, green innovation gives firms an opportunity to improve their business performance and competitive advantage, as well as to enhance their reputation [14.

Most of the initial research on GSCM focuses on firms' environmental performance [16]. However, later studies show that GSCM performance is multidimensional, encompassing not only environmental performance but also operational, social, and economic performance $[17,7,10,11,14,18]$. The GSCM research has so far focused on the relationship between green innovation and performance or that between environmental collaboration and performance in a fragmentary way. Few studies have sought to identify the structural mechanism leading to GSCM performance.

This study analyzes whether export-based manufacturing firms achieve strong organizational performance by implementing environmental collaboration and green innovation as a strategic dimension of GSCM. Specifically, we seek to clarify how environmental collaboration in the supply chain affects environmental innovation capability and environmental performance in terms of supply chain collaboration. The study finds a direct effect of environmental collaboration on environmental innovation capacity and environmental performance in the green supply chain of Korean export-based manufacturing firms. This study also finds that environmental collaboration affects export performance through environmental innovation capacity and environmental performance.

\section{Theoretical Background}

\subsection{GSCM}

GSCM is a management strategy and philosophy that considers the impact of the entire supply chain on environmental protection and economic development [19]. It combines environmental issues and to ensure environmental compliance and to promote the environmental capability of the entire supply chain [4].

In the past, firms could achieve competitive advantages such as cost reduction, quality improvement, and flexibility and speed improvements through efficient supply chain implementation. Today, however, due to the pressure exerted by customers' increasing environmental awareness, firms' supply chains must be integrated with environmental management. An organization that can eliminate environmental issues by implementing an appropriate environmental management system can create business opportunities unavailable to its competitors [6].

GSCM crosses various boundaries of SCM and highlights environmental issues for upstream and downstream business entities in the supply chain [20]. For example, GSCM cannot be implemented successfully in purchasing, product design and development, production, transportation, packaging, storage, disposal, or end-of-product-lifecycle management activities unless environmental issues are addressed first [21,22]. GSCM leverages the ability to integrate the process, technology, and environmental issues of supply chain partners to enhance their competitive advantage [23].

Zhu et al. (2008) [7] claim that GSCM involves the integrated lifecycle management of supply chains, environment-friendly products, packaging and process design, the environmental management of upstream and downstream supply chains, and closed-loop supply chains. The authors also state that integrating and measuring green practices within and between organizations can lead to sustainable competitive advantage. Wu et al. (2012) [24] posit that GSCM activities include supplier evaluation, internal environmental management, design, green supply chain integration, and environmental collaboration. Caniato et al. (2012) [25] show that firms should consider taking GSCM measures such as reducing packaging and waste, designing more environmentally friendly products, reducing carbon emissions during product production and distribution, cooperating with suppliers, and reverse logistics systems. 
GSCM is an important new way to obtain profits and market share while lowering firms' environmental risks and impacts. Many researchers have argued that GSCM is an important success factor for firms' sustainable development. While economic performance must be considered as well as environmental performance, GSCM is considered a very important success factor in firms' sustainable growth and development [24].

GSCM is being studied not only by academia but also by industry. Concerns about regulations, globalization, and corporate reputation, as well as pressure from customers, competitors, and environmental groups, are among the driving forces behind the implementation of GSCM practices [6]. Understanding and implementing GSCM are essential not only for enhancing profitability but also for securing and maintaining a competitive global position. To achieve sustainable development, firms are redesigning their products and adopting new technologies for processes, even when the SCM business model changes [1].

\subsection{Environmental Collaboration}

The green supply chain has attracted attention because of the new emphasis on corporate responsibility for climate change, but it is difficult for environment-friendly countermeasures to cope with that challenge. Environmental collaboration between firms in the supply chain must be smooth, so that the environmental quality of the product at the final supply chain stage can be assured. It is necessary to establish a high level of environmental collaboration among partner firms in the green supply chain. Smooth environmental collaboration can enhance organizational performance via information exchange and joint technological innovation between member firms [27].

Vachon and Klassen (2008) [28] point out that environmental collaboration in the green supply chain is a joint planning and participation activity through which suppliers and customers can solve environmental problems. In other words, environmental collaboration constitutes a collaborative relationship wherein a manufacturer shares its environmental vision and goals with its suppliers in the supply chain and tries to solve supply chain problems together to achieve these goals.

Huang and $\mathrm{Li}$ (2017) [14] argue that conducting effective green management requires firms to develop coordination capabilities and establish a vision based on strong integration among organizational members. This coordination ability involves not only sharing and disseminating market knowledge but also promoting the integration of market knowledge into products and processes for improvement. In other words, environmental collaboration among partners in the green supply chain is key to enhancing its performance. The research shows that manufacturers engaged in environmental collaboration with suppliers and customers can develop their organizational competencies, which in turn improves environmental performance as well as other factors, such as cost and quality. Therefore, firms need to collaborate and coordinate among members performing various functions to implement green practices such as life cycle analysis and environmental activity design [29].

Collaborative relationships can be divided into two types: internal, comprising interorganizational functional collaboration; and external, comprising collaboration between partner firms. To improve environmental sustainability, manufacturers must implement internal environmental management practices and collaborate with external suppliers and customers [10]. The scope of GSCM practices ranges from green purchasing and dealing with suppliers, manufacturers, customers, and reverse logistics to the fully integrated supply chain. Firms seeking to gain the greatest benefit from environmental management processes should integrate their interdepartmental efforts and other supply chain members (such as suppliers and customers) into these processes [11].

Internal collaboration comprises the activities within the enterprise required to meet customer requirements [30]. Coordination among functional departments along with the entire supply chain is the most important factor in improving environmental management [7]. Much of the research on firms' environmental issues has examined firms' internal operations, such as environmental product labeling, departmental environmental audits, EMS, environmental reports for internal evaluation, 
and ISO 14001 certification [11]. Internal GSCM implementation is recognized as a systematic and comprehensive internal mechanism for achieving superior performance [19].

External collaboration is the extent to which a firm collaborates with external partner firms [30]. Barratt (2004) [31] states that external activities for the downstream chain include customer relationship management, collaborative demand planning, demand replenishment, and shared distribution, while external activities for the upstream chain include supplier relationship management, supplier planning and production schedules, collaborative design, and collaborative transportation. Establishing a close and long-term business relationship with suppliers and customers is critical to the success of GSCM implementation [10].

Manufacturers manage suppliers' environmental performance to ensure that their materials and equipment are produced through green processes. Suppliers are considered important partners in the supply chain because they can help support the organization's environmental initiatives and improve the environmental performance of the overall supply chain [11]. Businesses also need to integrate ecological aspects into product and process design to meet customer needs [32]. As customers' environmental pressures grow, it becomes increasingly important to collaborate with them on green packaging, achieve environmental goals jointly, and establish joint environmental plans [11].

\subsection{Green Innovation Capacity}

The importance of green innovation as part of firms' innovation capacity has recently increased, along with the emergence of sustainability management as a vital issue. Innovation is an important mechanism for enhancing the ability of a company to maintain its competitive advantage. Green innovation capacity plays an important role in creating an enterprise's competitive advantage in the era of environmental protection [14]. Since the early 2000s, global interest in ecological environment has led to green innovation, represented by green products and processes. Firms now recognize eco-innovation as a source of competitive advantage. To meet eco product criteria and satisfy their customers' quality requirements, they must develop sustainable green innovation capabilities rather than pursue temporary green innovation [18].

Green innovation is an improvement in products or processes that reduces environmental burdens or achieves sustainability goals. Green innovation posits that firms can reduce their environmental impacts to achieve environmental goals and integrate the resultant environmental benefits. Green innovation aims to systematically coordinate and implement these strategies across the supply chain, from new product and service development to consumption [33]. Firms improve their economic and environmental performance through green innovation by increasing operational efficiency, reducing costs, and meeting the needs of environmentally conscious customers [34. Green innovation not only reduces negative environmental impacts, but also increases firms' economic and social performance through waste and cost reduction [18]. Therefore, green innovation capability is a firm-specific capability that can minimize the environmental impacts of all firm activities based on the knowledge gained from inside and outside the firm [35].

Green innovation has three main categories: green product innovation, green process innovation, and green management innovation [13]. Green product innovation is introduction of new or significantly improved products in response to environmental problems. Firms implement green product innovation to improve their market standing, identify brand names, leap ahead, create breakthroughs, and attract new customers [18]. In other words, green product innovation seeks to improve the quality and safety of products by promoting sustainability and environmental solutions, thereby securing competitive advantage and increasing profits [34]. Product-centered green innovation seeks to reduce environmental burdens by using fewer hazardous and non-renewable materials in product development, taking into account the environmental impacts on product design, packaging, and material use [36].

In addition, firms implement green process innovation in their manufacturing processes to shorten production times and reduce costs. Green process innovation seeks to modify manufacturing processes and systems to produce eco-products that meet green targets such as 
energy conservation, pollution prevention, and waste recycling [18]. Implementing green process innovation allows firms to store raw materials, recycle waste, reduce resource use, lower costs, and improve overall resource productivity [36].

\subsection{GSCM Performance}

Measuring performance is important for firms seeking to identify problems and sustain customer satisfaction, and thus succeed in a competitive environment. Luthra et al. (2016) [37] divide GSCM performance into two dimensions: environmental performance and economic performance. Environmental performance is the degree to which GSCM introduction and implementation produce results such as the reduction of air pollutants or harmful substances. Environmental performance can be measured by assessing waste emissions, pollutant emissions, and recycling rates [13]. The research suggests that the most direct result of green product innovation using eco-raw materials is the firm's environmental performance [38]. Developing green products not only improves the product but also reduces the amount of waste generated during product manufacturing [28]. Firms with eco-product innovation capabilities also reduce pollutant emissions from the beginning of product design through product lifecycle analysis [39].

Economic performance concerns firm outcomes or perceived success in achieving goals related to revenue growth, profit growth, market share gains, and operational efficiency [6]. The research indicates that implementing GSCM can increase the economic performance of new market entry opportunities, product prices, profits, market share, and sales. Thus, GSCM practices have become an important strategy by which business organizations can enhance profits and increase market share [37].

\section{Research Model and Hypothesis}

\subsection{Research Model}

This study proposes a model reflecting the structural relationship between environmental collaboration, green innovation capacity, and GSCM performance based on previous studies in order to identify the factors affecting export manufacturers' performance from the green supply chain perspective.

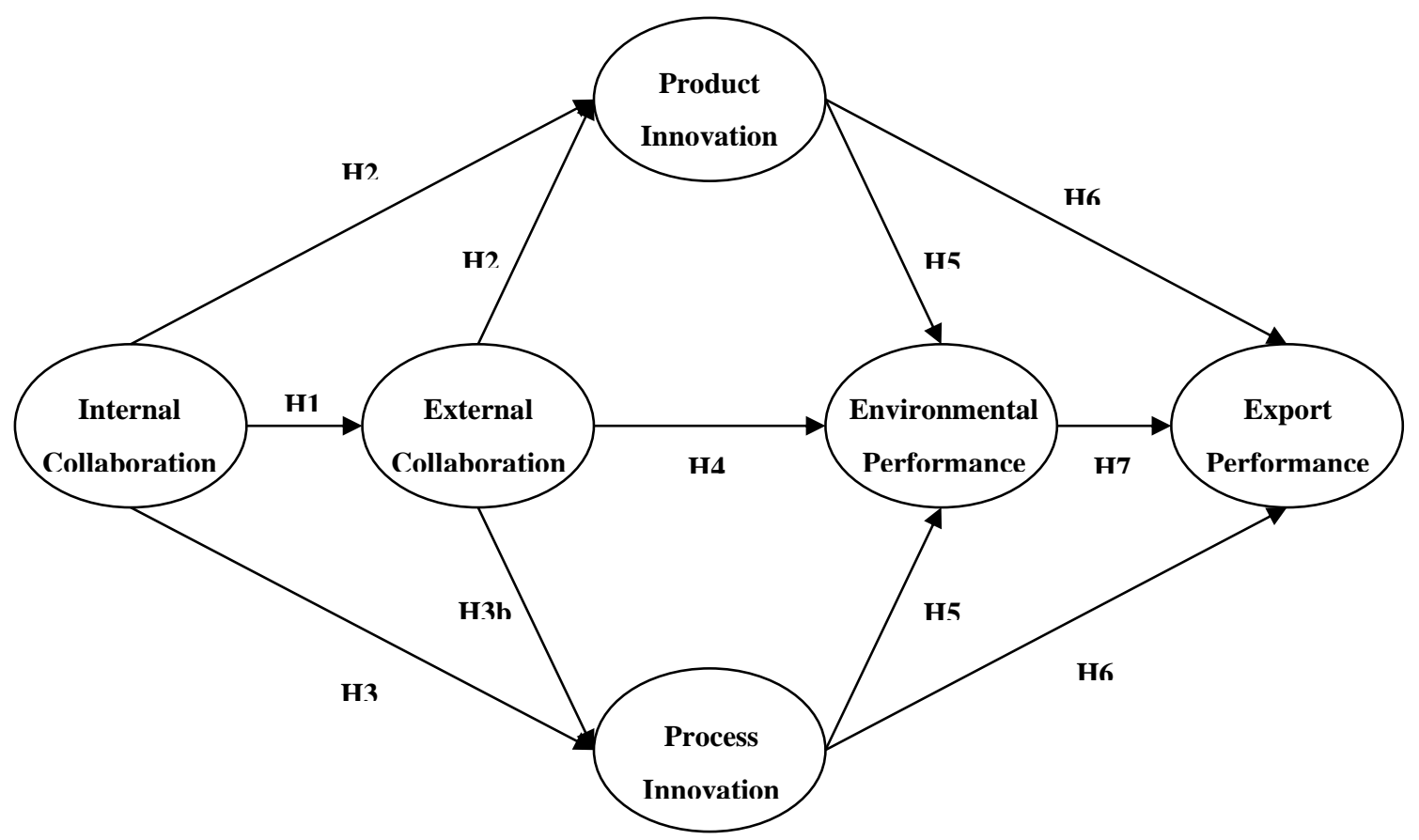

Figure 1 Proposed conceptual model 


\subsection{Hypothesis Development}

Internal collaboration in the supply chain is the foundation upon which firms can absorb, interpret, and apply external information more quickly [40]. It is difficult to achieve a high level of integration with external suppliers and customers if strategic collaboration or alliances do not interact with one another to ensure consistency among goals and practices across the firms' functional units [41]. Inadequate internal collaboration can lead to weaker processes or disconnects in the firm, resulting in an inability to resolve potential conflicts, set up synchronized processes, or facilitate operations with external partners [11].

Studies on SCM have suggested internal GSCM activities as the leading factors in external GSCM activities. Koufteros et al. (2005) [42] find that internal collaboration in product development activities such as product design, process design, and manufacturing activities directly strengthen collaboration with suppliers and customers. Zhao et al. (2011) [40] argue that firms with high levels of internal communication and coordination capabilities are highly likely to achieve high levels of external collaboration. Yang et al. (2013) [43] report that internal GSCM activities have a positive effect on external GSCM activities. Zhu et al. (2013) [44] suggest that internal GSCM activities in internal environmental management and green purchasing have positive effects on external GSCM activities such as green purchasing, customer collaboration, and investment return. Finally, Laari et al. (2016) [45] argue that internal GSCM activities have a positive effect on environmental collaboration with suppliers and customers. Therefore, the following hypothesis is proposed:

Hypothesis 1. Internal collaboration has a positive effect on external collaboration.

As concerns about environmental issues and regulations grow, customers and buyers are increasingly asking their suppliers to provide products and materials that take environmental issues into account. Therefore, it is necessary to work closely with suppliers at the beginning of the product development process to reduce the materials and packaging that can adversely affect the environment [13].

Manufacturers and supply chain partners strive to achieve common environmental goals [19]. During green management, powerful social networks motivate partners to relocate and exchange knowledge. Manufacturers develop the new knowledge and skills that are the foundation of green innovation by increasing collaborative problem solving through social interaction in the network. They can thus improve their ability to manage risk, innovate, and adapt to change [14].

Green innovation initiatives rely on the knowledge, expertise, and commitment of its members in the value creation process [46]. Firms require coordination capabilities to integrate members serving different functions into the innovation process. Coordination capabilities allow the organization to blur the boundaries between units and create common interests that support the sharing and application of the required knowledge within the organization. Organizational members can develop the trust and collaborative effort required to coordinate green innovation practices such as life cycle analysis and design for environmental activities. Therefore, coordination capabilities enable firms to integrate environmental issues into strategic planning and advance new green product innovation [14].

Vachon and Klassen (2008) [28] suggest that environmental collaboration with key suppliers and customers is positively associated with new technology and logistics practices. The sustainability research has suggested that external organizational clusters can enhance green innovation practices by promoting knowledge transfer and skill-outs to integrate various types of innovation [47]. Likewise, Yu et al. (2014) [11] suggest that internal GSCM plays an important role in reducing production costs and improving product quality by promoting information sharing among functional areas, thereby simultaneously improving green operation and process design. The willingness of supply chain members to share knowledge of inter- and intra-organizational environmental operations and strategies formally and voluntarily helps to improve sustainable operations and environmentally oriented products and services [48]. Therefore, the following hypothesis is proposed: 
Hypothesis 2a. Internal collaboration has a positive effect on product innovation. Hypothesis $2 \mathrm{~b}$. External collaboration has a positive effect on product innovation. Hypothesis 3a. Internal collaboration has a positive effect on process innovation. Hypothesis $3 b$. External collaboration has a positive effect on process innovation.

A recent study on supply chains lists environmental collaboration as a key factor in securing competitive advantage and sustainable development for manufacturing firms. Vachon and Klassen (2008) [28] find that collaboration with research suppliers positively affects operational performance, such as delivery quality, as well as environmental performance. Green et al. (2012) [10] find that green purchasing, collaboration with customers, green design, and producer responsibilities have positive impacts on environmental and operational performance. Paulraj et al. (2014) [49] suggest that firms need to have a process mechanism for environmental collaboration that can realize excellent environmental performance via environmental collaboration in the supply chain. Yu et al. (2014) [11] reveal that green supply chain integration with suppliers and customers can enable manufacturers to achieve high levels of operational performance. Luzzini et al. (2015) [12] argue that commitment to sustainability in procurement and supply management enhances collaboration within and between firms, leading to improved performance. Therefore, the following hypothesis is proposed:

Hypothesis 4. External collaboration has a positive effect on environmental performance.

Green innovation in products and processes not only reduces negative impacts on the environment, but also increases firms' competitive advantage $[35,13,14]$. Green product innovation enables firms to respond to market needs and governments' environmental requirements, while also enhancing the resource effects needed to optimize environmental benefits in the product lifecycle. Green process innovation requires firms to reduce their clean production costs and pollutant emissions to meet the requirements of environmental regulations [13,50]. Firms that invest significantly in green innovation efforts can recoup their environmental costs by minimizing production wastage and increasing productivity $[46,13]$. Green innovation can help firms meet their environmental protection obligations and avoid public protests and penalties from government regulators [14].

Chiou et al. (2011) [13] analyze the relationship between green innovation, environmental performance, and competitive advantage for 124 Taiwanese firms. They find that product and process innovation have positive effects on environmental performance and that a firm's green innovation is strongly associated with its competitive advantage. Thus, green product and process innovation are positively associated with environmental performance. Therefore, the following hypotheses are proposed:

Hypothesis 5a. Product innovation has a positive effect on environmental performance. Hypothesis $5 b$. Process innovation has a positive effect on environmental performance.

Firms adopt green innovation strategies to integrate environmental protection goals with economic performance goals [19]. The research suggests that investment in green innovation improves firms' economic performance [39,13,46]. Chen (2008) [39] finds that green innovation pioneers have a first-mover advantage and impose relatively high prices on their green products. Green innovation also improves corporate image. Huang and Wu (2010) reveal that high-tech firms can positively impact their financial performance if they develop green products and make processes more environmentally efficient. Chiou et al. (2011) [13] point out that green innovation can improve a firm's environmental performance and enhance its competitive advantage. They also suggest that green product innovation and green process innovation have positive relationships with organizational performance. Therefore, the following hypotheses are proposed. 
Hypothesis 6a. Product innovation has a positive effect on export performance. Hypothesis $6 \mathrm{~b}$. Process innovation has a positive effect on export performance.

Improving efficiency through collaborative SCM enhances performance, such as in cost reduction, new product development, and customer satisfaction improvement. It can also enhance the export performance of a manufacturing enterprise [51]. For resource-based theory, environmental performance and organizational performance are related because they are both based on firms' strategic resources. The environmental benefits of improving environmental performance lead to organizational performance enhancements such as reduced inventory levels, improved product quality, improved customer service excellence, and strengthened customer relationships[52]. Purba (2002) [17] found that the higher the level of GSCM implementation, the greater the firm's environmental performance, and the stronger the positive effect of environmental performance on economic performance. Purba (2002) [17] suggests that the environmental performance of the GSCM implementation of export manufacturing enterprises should have a positive relationship with export performance. Therefore, the following hypothesis is proposed.

Hypothesis 7. Environmental performance has a positive effect on export performance.

\section{Research Method}

\subsection{Data Collection and Sample}

This study seeks to clarify the structural relationship between environmental collaboration, green innovation capacity, and GSCM performance in order to identify the factors affecting GSCM performance. For that purpose, this study collected data on Korean exporting manufacturing firms to set up its research model. Questionnaires were distributed from September to December 2018. Overall, 345 copies were collected (for a 34.5\% recovery rate), and 327 cases were selected as valid samples.

Industries that are heavily influenced by international environmental regulations account for a large portion of the sample: $18.1 \%$ of the sample firms are in the mechanical, steel, and metal industries; $36.2 \%$ are in the electrical, electronics, and telecommunications industries; and $16.8 \%$ are in the petroleum, chemical, and plastics industries. The sample characteristics are summarized in Table 1.

Table 1. Sample Characteristics $(n=315)$

\begin{tabular}{clcc}
\hline & Category and Items & Sample Size & Ratio (\%) \\
\hline \multirow{2}{*}{$\begin{array}{c}\text { Less than 5 years } \\
\text { Years }\end{array}$} & $5-10$ years & 38 & 11.6 \\
& $10-20$ years & 76 & 23.1 \\
& $20-30$ years & 130 & 39.5 \\
& More than 30 years & 48 & 14.6 \\
& Less than $\$ 10 \mathrm{M}$ & 37.2 & 7.9 \\
Annual & $\$ 10-\$ 30 \mathrm{M}$ & 26 & 12.5 \\
Sales & $\$ 30-\$ 50 \mathrm{M}$ & 41 & 30.4 \\
& $\$ 50-\$ 100 \mathrm{M}$ & 100 & 32.5 \\
& More than $\$ 100 \mathrm{M}$ & 107 & 16.7
\end{tabular}




\section{Machinery/Steel/Metal}

Petroleum/Chemical/Plastics

Electric/Electronic/Communication

Bio/Medical

Other
60

54

119

46

23
18.2

16.4

36.2

14.0

7.0

\subsection{Measures}

To ensure the reliability and validity of our measurement tools, we used measurement items verified in prior studies, modified and supplemented as needed to suit the purpose of this study. First, the items reflecting internal and external collaboration (in terms of environmental collaboration) were developed by referring to Zhu and Sarkis (2004) [53], Zhu et al. (2010) [54], and $\mathrm{Yu}$ et al. (2014) [11]. Internal collaboration was measured using four items: "cross-functional collaboration for environmental improvements," "environmental compliance and auditing programs," "environmental management certification (e.g., ISO14000/ISO14001 certification), and "environmental management systems operation." External collaboration was measured using four items: "collaborate with suppliers for environmental objectives," "environmental audit for suppliers' internal management," "collaborate with customers for eco design," and "collaborate with customers for cleaner production." Second, product and process innovation capabilities (in terms of innovation capacities) were developed by referring to Chen et al. (2008) [39], Chiou et al. (2011) [13], and Huang and Li (2017) [14]. Product innovation capability was measured using four items: "environmentally friendly material," "environmentally friendly packaging," "recovery of products and recycling," and "eco-labeling." Process innovation capability was measured using four items: "energy savings," "pollution prevention," "waste recycling," and "less toxicity." Third, the environmental performance item was developed by referring to Zhu and Sarkis (2004) [53], Chiou et al. (2011) [13], and Huang and Li (2017) [14]. Environmental performance was measured using four items: "reduction of air emissions," "reduction of waste water," "reduction of solid wastes," and "reduction of hazardous/harmful/toxic materials consumption." Fourth, the export performance item was developed by referring to Purba (2002) [17], Cao and Zhang (2011) [55], and Patel et al. (2013) [51]. Export performance was measured using four items: "(Last 3 years) satisfaction with increase in export sales," (last 3 years) satisfaction with increase in export rate," "(last 3 years) satisfaction with the increase in export market share," and "(last 3 years) overall satisfaction with export performance."

\section{Research Method}

\subsection{Analysis Method}

This study's hypotheses were tested by analyzing the proposed structural equation model using Amos 20.0. The analysis of the structural equation model was performed by first estimating the measurement model and then applying the two-step approach and the maximum likelihood (HD) method to estimate the structural model.

\subsection{Measurement Model}

This study conducted confirmatory factor analysis to ensure the content validity of the measurement tool. For this purpose, $\chi^{2}$, standard $\chi^{2}\left(\chi^{2} / \mathrm{df}\right)$, RMSEA, GFI, CFI, and TLI were used to check the goodness of fit. The initial model did not exceed the standard fitness threshold, so a modified indices analysis was conducted [56], and measurement items that impede unidimensional 
value were removed (EVP3 and EPP4). In a confirmatory factor analysis of the modified measurement model $\left(\chi^{2}=375.119(\mathrm{P}=.000), \chi^{2} / \mathrm{df}=1.934, \mathrm{RMSEA}=.057, \mathrm{GFI}=.908, \mathrm{CFI}=.950\right.$, TLI $=.940)$, all the indices suggested the fitness of the measurement model. After the measurement model's fitness was verified, we analyzed its reliability and validity. For convergent validity to be confirmed, construct reliability (C.R.) should exceed 0.7 , and the average variance extracted (AVE) should exceed 0.5. Discriminatory validity is judged to be valid if the square of the correlation coefficient between the two potential factors is lower than the AVE. The results of this study's tests of convergent validity and discriminatory validity are presented in Tables 2 and 3, respectively.

Table 2. Confirmatory factor analysis based on reliability

\begin{tabular}{|c|c|c|c|c|c|}
\hline \multicolumn{2}{|c|}{ Measurement Item } & \multirow{2}{*}{$\begin{array}{c}\text { Factor L.D. } \\
.763\end{array}$} & \multirow{5}{*}{$\begin{array}{l}\text { C.R. } \\
\\
.902\end{array}$} & \multirow{5}{*}{$\begin{array}{l}\text { AVE } \\
.697\end{array}$} & \multirow{5}{*}{$\begin{array}{c}\text { Crb. Alpha } \\
\text {.856 }\end{array}$} \\
\hline \multirow{4}{*}{$\begin{array}{c}\text { Internal } \\
\text { Collaboration }\end{array}$} & EIC1 & & & & \\
\hline & EIC2 & .781 & & & \\
\hline & EIC3 & .796 & & & \\
\hline & EIC4 & .756 & & & \\
\hline \multirow{4}{*}{ Collaboration } & EEC1 & .714 & \multirow{4}{*}{.887} & \multirow{4}{*}{.664} & \multirow{4}{*}{.794} \\
\hline & EEC2 & .696 & & & \\
\hline & EEC3 & .704 & & & \\
\hline & EEC4 & .686 & & & \\
\hline \multirow{4}{*}{$\begin{array}{c}\text { Product } \\
\text { Innovation }\end{array}$} & PDI1 & .751 & \multirow{4}{*}{.931} & \multirow{4}{*}{.773} & \multirow{4}{*}{.863} \\
\hline & PDI2 & .770 & & & \\
\hline & PDI3 & .858 & & & \\
\hline & PDI4 & .822 & & & \\
\hline \multirow{4}{*}{ Innovation } & PCI1 & .746 & \multirow{4}{*}{.924} & \multirow{4}{*}{.754} & \multirow{4}{*}{.876} \\
\hline & PCI2 & .773 & & & \\
\hline & PCI3 & .832 & & & \\
\hline & PCI4 & .779 & & & \\
\hline \multirow{3}{*}{$\begin{array}{c}\text { Environmental } \\
\text { Performance }\end{array}$} & EVP1 & .692 & \multirow{3}{*}{.890} & \multirow{3}{*}{.730} & \multirow{3}{*}{.772} \\
\hline & EVP2 & .815 & & & \\
\hline & EVP4 & .687 & & & \\
\hline \multirow{3}{*}{$\begin{array}{c}\text { Export } \\
\text { Performance }\end{array}$} & EPP1 & .844 & \multirow{3}{*}{.916} & \multirow{3}{*}{.788} & \multirow{3}{*}{.821} \\
\hline & ЕРP2 & .877 & & & \\
\hline & ЕРP3 & .641 & & & \\
\hline
\end{tabular}


Table 3. Discriminant Validity

\begin{tabular}{c|c|c|c|c|c|c}
\hline Variable & 1 & 2 & 3 & 4 & 5 & 6 \\
\hline $\begin{array}{c}\text { 1. Internal } \\
\text { Collaboration }\end{array}$ & $.697^{* *}$ & & & & & \\
\hline $\begin{array}{c}\text { 2. External } \\
\text { Collaboration }\end{array}$ & $.464^{*}$ & $.664^{* *}$ & & & & \\
\hline $\begin{array}{c}\text { 3. Product } \\
\text { Innovation }\end{array}$ & $.326^{*}$ & $.434^{*}$ & $.773^{* *}$ & & & \\
\hline $\begin{array}{c}\text { 4. Process } \\
\text { Innovation }\end{array}$ & $.386^{*}$ & $.473^{*}$ & $.416^{*}$ & $.754^{* *}$ & & \\
\hline $\begin{array}{c}\text { 5. Environmental } \\
\text { Performance }\end{array}$ & $.377^{*}$ & $.288^{*}$ & $.316^{*}$ & $.349^{*}$ & $.730^{* *}$ & \\
\hline $\begin{array}{c}\text { 6. Export } \\
\text { Performance }\end{array}$ & $.246^{*}$ & $.294^{*}$ & $.386^{*}$ & $.325^{*}$ & $.324^{*}$ & $.788^{* *}$ \\
\hline
\end{tabular}

Note: *squared value of correlation $\left(\emptyset^{2}\right) ;{ }^{* *} \mathrm{AVE}$ (average variance extracted)

\subsection{Structural Model}

Then, structural model analysis was conducted to verify the research hypotheses. In the test results $\left(\chi^{2}=404.465[\mathrm{P}=.000], \chi^{2} / \mathrm{df}=2.043, \mathrm{RMSEA}=.043, \mathrm{GFI}=.901, \mathrm{CFI}=.943, \mathrm{TLI}=.933\right)$, all the indices suggested that the structural model was fit.

\subsection{Hypotheses Test}

After structural model's fitness was confirmed, research hypotheses were tested. As a result, first, concerning the structural relationships in environmental collaboration, internal collaboration appeared to have an effect on external collaboration $(\beta=.609$; C.R. $=9.202, p=.000)$; therefore, H1 was supported. Second, regarding the relationship between environmental collaboration and product innovation, both internal collaboration $(\beta=.176 ;$ C.R. $=2.321, \mathrm{p}=.020)$ and external collaboration $(\beta=.562 ;$ C.R. $=5.776, p=.000)$ had positive effects on product innovation; therefore, $\mathrm{H} 2 \mathrm{a}$ and $\mathrm{H} 2 \mathrm{~b}$ were supported. Third, for the relationship between environmental collaboration and process innovation, both internal collaboration $(\beta=.234 ;$ C.R. $=3.118, p=.002)$ and external collaboration $(\beta=.567$; C.R. $=5.891, p=.000)$ had positive effects on process innovation; therefore, $\mathrm{H} 3 \mathrm{a}$ and $\mathrm{H} 3 \mathrm{~b}$ were supported. Fourth, regarding the relationship between external collaboration and environmental performance, external collaboration appeared to have an effect on environmental performance $(\beta=.143$; C.R. $=1.453, \mathrm{p}=.146)$; therefore, $\mathrm{H} 4$ was not supported. Fifth, concerning the relationship between green innovation capacity and environmental performance, both product innovation $(\beta=.188 ;$ C.R. $=2.633, p=.008)$ and process innovation $(\beta=.237 ;$ C.R. $=3.238, p=.001)$ had positive effects on environmental performance; therefore, H5a and H5b were supported. Sixth, regarding the relationship between green innovation capacity and export performance, both product innovation $(\beta=.370 ;$ C.R. $=4.991, p=.000)$ and process innovation $(\beta=.203 ;$ C.R. $=2.831, p=.005)$ had positive effects on export performance, therefore, H6a and H6b were supported. Finally, for the relationship between environmental performance and export performance, environmental 
performance appeared to have an effect on export performance $(\beta=.326$; C.R. $=3.091, \mathrm{p}=.002)$; therefore, H7 was supported. The results of the hypothesis tests are summarized in Table 4 and Figure 2.

Table 4. Hypotheses and results

\begin{tabular}{c|c|r|r|c}
\hline \multicolumn{2}{c|}{ Hypothesis Path } & $\begin{array}{c}\text { Estimate } \\
(\beta)\end{array}$ & $\begin{array}{c}\text { C.R. } \\
(\mathbf{t})\end{array}$ & Results \\
\hline $\mathrm{H} 1$ & Internal Collaboration $\rightarrow$ External Collaboration & .609 & $9.202^{* *}$ & Supported \\
\hline $\mathrm{H} 2 \mathrm{a}$ & Internal Collaboration $\rightarrow$ Product Innovation & .176 & $2.321^{*}$ & Supported \\
\hline $\mathrm{H} 2 \mathrm{~b}$ & External Collaboration $\rightarrow$ Product Innovation & .562 & $5.776^{* *}$ & Supported \\
\hline $\mathrm{H} 3 \mathrm{a}$ & Internal Collaboration $\rightarrow$ Process Innovation & .234 & $3.118^{* *}$ & Supported \\
\hline $\mathrm{H} 3 \mathrm{~b}$ & External Collaboration $\rightarrow$ Process Innovation & .567 & $5.891^{* *}$ & Supported \\
\hline $\mathrm{H} 4$ & External Collaboration $\rightarrow$ Environmental Performance & .143 & 1.453 & Not Supported \\
\hline $\mathrm{H} 5 \mathrm{a}$ & Product Innovation $\rightarrow$ Environmental Performance & .188 & $2.633^{* *}$ & Supported \\
\hline $\mathrm{H} 5 \mathrm{~b}$ & Process Innovation $\rightarrow$ Environmental Performance & .237 & $3.238^{* *}$ & Supported \\
\hline $\mathrm{H} 6 \mathrm{a}$ & Product Innovation $\rightarrow$ Export Performance & .370 & $4.991^{* *}$ & Supported \\
\hline $\mathrm{H} 6 \mathrm{~b}$ & Process Innovation $\rightarrow$ Export Performance & .203 & $2.831^{* *}$ & Supported \\
\hline $\mathrm{H} 7$ & Environmental Performance $\rightarrow$ Export Performance & .326 & $3.091^{* *}$ & Supported \\
\hline
\end{tabular}

Note $:{ }^{*} \mathrm{p}<.05,{ }^{* *} \mathrm{p}<.01,{ }^{* * *}<.001$

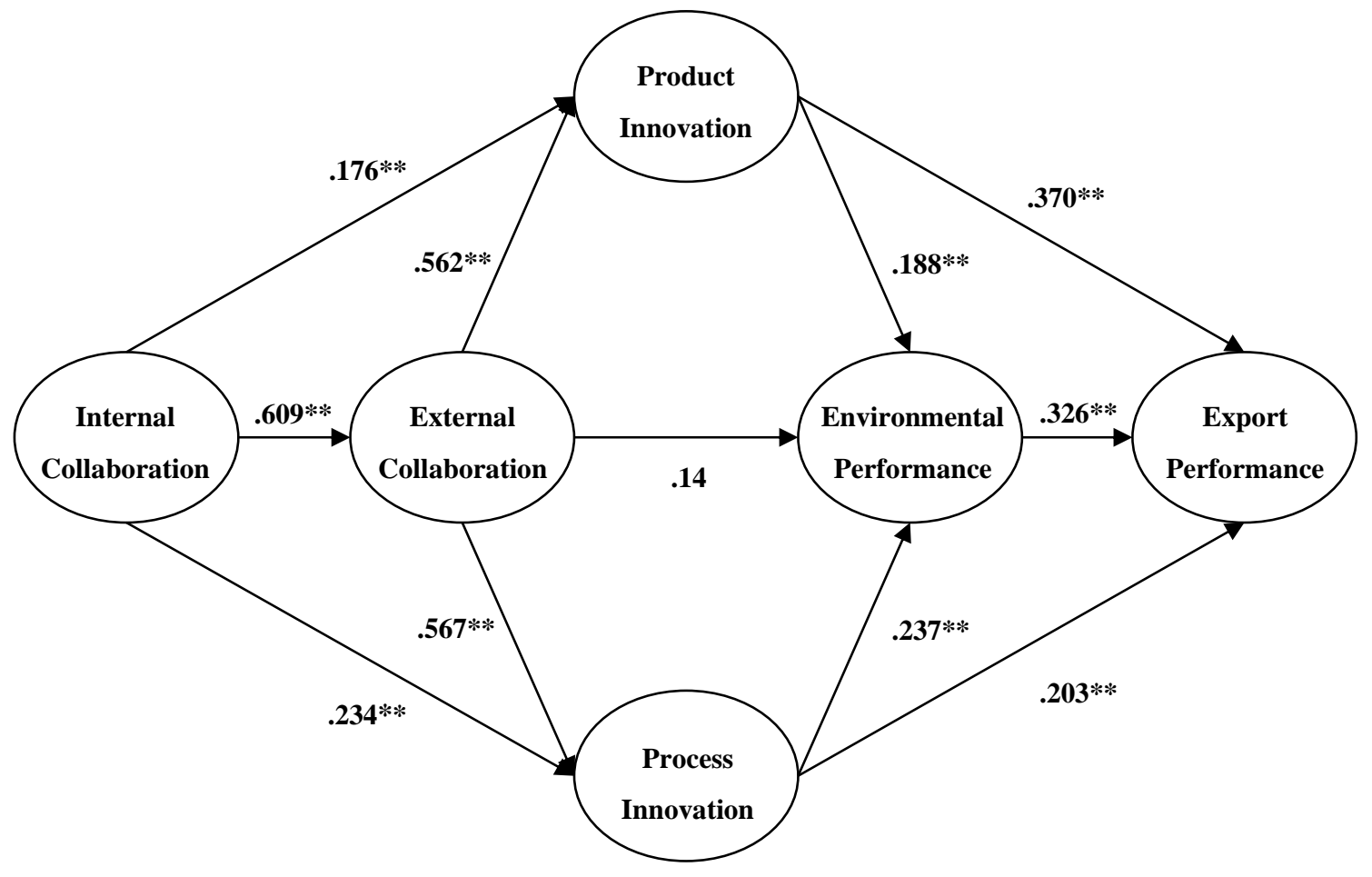

Note: ${ }^{*} \mathrm{p}<.05,{ }^{* *} \mathrm{p}<.01 ; \mathrm{ns}=$ insignificant at the 0.05 level

Figure 2. Research model and path efficiency 


\section{Conclusions}

\subsection{Discussion of Results}

In recent years, understanding and implementing GSCM has been recognized as indispensable not only for enhancing profitability but also for securing and maintaining global competitive advantage. Firms can create more business opportunities if they can solve environmental problems through their GSCM capabilities [6]. Therefore, this study aims to identify the factors affecting the performance of Korean export-based manufacturers from the perspective of the green supply chain. The structural relationships between environmental collaboration, innovation capacity, and GSCM performance were empirically identified through a literature review, and the subsequent analysis produced the following results.

First, internal collaboration has a positive effect on external collaboration in the structural relationship between the sub-dimensions of environmental collaboration. Firms with a high level of internal communication and coordination capabilities in the supply chain are more likely to achieve a high level of external collaboration, whereas it is difficult to achieve high levels of integration with internal suppliers and customers [41,40,11]. A number of studies on GSCM have suggested internal GSCM as an antecedent factor of external GSCM [10,43,44,45]. This study confirmed that collaboration between the functions and operations of an environmental management system seeking to improve the environment has a direct effect on collaboration with suppliers and customers designed to achieve environmental goals.

Second, internal and external collaboration have positive effects on product innovation and process innovation in the relationship between environmental collaboration and green innovation capacity. Green innovation seeks to systematically coordinate and implement these strategies across the supply chain, from new product and service development to consumption [33]. Green innovation requires that suppliers and customers work closely early on in the product development process to reduce materials and packaging that can negatively impact the environment [13]. In the supply chain, environmental collaboration can improve both product design and process design, thereby allowing firms to attain their environmental goals and improve their economic performance. Therefore, this study has confirmed that a high level of collaboration with internal organizations and partner firms in the supply chain has a direct impact on green innovation capacity.

Third, external collaboration did not have a significant effect on environmental performance. This study found that environmental collaboration in the green supply chain positively affects green innovation capacity but does not directly affect environmental performance. Green supply chain integration is the driving force for firms' achievement of high levels of operational performance. Firms should establish a mechanism for environmental collaboration in order to realize strong environmental performance [49]. Therefore, environmental performance can be achieved only when firms' green innovation capability is implemented based on environmental collaboration in the green supply chain [13].

Fourth, product innovation and process innovation have positive effects on environmental performance in the relationship between innovation capability and environmental performance. Green innovation aims to systematically adjust and implement green improvements throughout the supply chain, from new product and service development to consumption, in order to achieve environmental goals [33]. Green innovation not only reduces negative impacts on the environment, but also increases firms' competitive advantage $[35,13,14]$. This study confirmed that product innovation capacities such as eco materials and packaging, product recovery, and recycling, as well as process innovation capacities such as energy conservation, pollution prevention, and waste recycling, have direct effects on environmental performance

Fifth, product innovation and process innovation have positive effects on export performance in relation to innovation capability and export performance. Green innovation leads to economic improvement and profitability for firms $[39,13,46]$. In other words, green products created through green product innovation and process innovation strengthen the firm's market position by enhancing the brand, increasing competitiveness, making breakthroughs, and attracting new 
customers [18]. Therefore, developing more green products and building more efficient processes have positive effects on economic performance [46].

Finally, environmental performance has a positive effect on export performance. The introduction and implementation of GSCM improves the economic performance of new market entry opportunities, product prices, profits, market share, and sales [37]. Therefore, GSCM is an important strategy for achieving economic performance and sustainable management in the market.

\subsection{Implications and limitations}

This study examined the influence of environmental collaboration on corporate performance through environmental innovation capacity from the viewpoint of the green supply chain. This study extends the GSCM literature by proposing GSCM as an integrated framework of environmental collaboration, approached from the perspective of environmental collaboration. Most previous GSCM studies have discussed environmental collaboration in terms of external collaboration, such as collaboration with supplier firms or environmental collaboration with customers. This study has proposed an integrated framework that considers environmental collaboration simultaneously with internal collaboration and external collaboration. In addition, this study has enhanced the scholarly understanding of GSCM by demonstrating that the path to achievement proceeds through the green innovation capacity of environmental collaboration. Previous studies have attempted to identify the factors affecting GSCM by considering only the direct relationship between environmental collaboration and performance, or between green innovation capacity and performance. However, this study has shown that environmental collaboration in the green supply chain environment positively affects green innovation capacity but does not directly affect environmental performance. Therefore, this study has presented a new research model by which to understand the GSCM mechanism, demonstrating the structural relationship between environmental collaboration, green innovation capability, and performance.

The results of this study offer implications that firm management can use to develop more effective GSCM strategies. The results clearly show that it is important to consider internal and external GSCM simultaneously when seeking sustainability in the supply chain. Export-based manufacturing firms will be able to contribute to environmental performance and business performance by developing more effective environmental strategies if they promote integrated environmental collaboration in GSCM. Therefore, the integrated environmental collaboration model proposed in this study provides more specific directions for export-based manufacturers who want to expand their environmental practices throughout the supply chain. As eco management emerges as a new management trend in the 21st century, firms will require sustainability management in order to survive in the top tier, and business management should move toward maximizing firm value. Implementing GSCM successfully requires key changes, such as conducting innovation activities from a long-term perspective rather than shaping the firm's image in order to satisfy internal and external stakeholders and show short-term results. In other words, firms must no longer simply adhere to external pressures when addressing environmental issues such as customer demands and production efficiency for green products and services; they must also gain sustainable competitive advantage. GSCM activities should thus be approached in a long-term, strategic way.

The data used in this study are based on export-based manufacturing firms in Korea. Focusing on a single country may limit the generalizability of the results. Testing the proposed model for other countries and comparing the results with those of this study would generate more advanced research results. In addition, as mentioned in previous studies, the effect of GSCM on firm performance may differ depending on the size of the firm and the time when GSCM was introduced. Future studies would provide more abundant implications for the green SCM management system by addressing these limitations. 


\section{References}

1. Sarkis, J.; Zhu, Q.; Lai, K. An organizational theoretic review of green supply chain management literature. Int. J. Prod. Econ. 2011, 130, 1-15. [CrossRef]

2. Woo, C.; Kim, M. G.; Chung, Y.; Rho, J. J. Suppliers' communication capability and external green integration for green and financial performance in Korean construction industry. J. Clean. Prod. 2016, 112, 483-493. [CrossRef]

3. Lee, S. Y.; Klassen, R. D.; Furlan, A.; Vinelli, A. The green bullwhip effect: Transferring environmental requirements along a supply chain. Int. J. Prod. Econ. 2014, 156, 39-51. [CrossRef]

4. Chu, S.; Yang, H.; Lee, M.; Park, S. The impact of institutional pressures on green supply chain management and firm performance: Top management roles and social capital. Sustainability. 2017, 9, 764. [CrossRef]

5. Joo, H. Y. The Causal Relationship Between Environmental Collaboration and Export Performance. Korea trade review. 2015, 40, 137-160. [CrossRef]

6. Liu, S.; Chang, Y. T. Manufacturers' closed-loop orientation for green supply chain management. Sustainability. 2017, 9, 222. [CrossRef]

7. Zhu, Q.; Sarkis, J.; Lai, K. H. Confirmation of a measurement model for green supply chain management practices implementation. Int. J. Prod. Econ. 2008, 111, 261-273. [CrossRef]

8. Li, D.; Zheng, M.; Cao, C.; Chen, X.; Ren, S.; Huang, M. The impact of legitimacy pressure and corporate profitability on green innovation: Evidence from China top 100. J. Clean. Prod. 2017, 141, 41-49. [CrossRef]

9. Jafarzadeh-Ghoushchi, S. Qualitative and Quantitative Analysis of Green Supply Chain Management (GSCM) Literature From 2000 to 2015. Supply Chain Manag. Int. J. 2018, 7, 77-86. [CrossRef]

10. Green Jr, K. W.; Zelbst, P. J.; Meacham, J.; Bhadauria, V. S. Green supply chain management practices: impact on performance. Supply Chain Manag. Int. J. 2012, 17, 290-305. [CrossRef]

11. Yu, W.; Chavez, R.; Feng, M.; Wiengarten, F. Integrated green supply chain management and operational performance. Supply Chain Manag. Int. J. 2014, 19, 683-696. [CrossRef]

12. Luzzini, D.; Brandon-Jones, E.; Brandon-Jones, A.; Spina, G. From sustainability commitment to performance: The role of intra-and inter-firm collaborative capabilities in the upstream supply chain. Int. J. Prod. Econ. 2015, 165, 51-63. [CrossRef]

13. Chiou, T. Y.; Chan, H. K.; Lettice, F.; Chung, S. H. The influence of greening the suppliers and green innovation on environmental performance and competitive advantage in Taiwan. Transp. Res. E Logist. Transp. Rev. 2011, 47, 822-836. [CrossRef]

14. Huang, J. W.; Li, Y. H. Green innovation and performance: The view of organizational capability and social reciprocity. J. Bus. Ethics, 2017, 145, 309-324. [CrossRef]

15. Saunila, M.; Ukko, J.; Rantala, T. Sustainability as a driver of green innovation investment and exploitation. J. Clean. Prod. 2018, 179, 631-641. [CrossRef]

16. Carter, C. R.; Kale, R.; Grimm, C. M. Environmental purchasing and firm performance: an empirical investigation. Transp. Res. E Logist. Transp. Rev. 2000, 36, 219-228. [CrossRef]

17. Purba, R.; Greening the Supply Chain: A New Initiative in South East Asia. Int. J. Oper. Prod. Manag. 2002, 22, 632-655. [CrossRef]

18. Zailani, S.; Govindan, K.; Iranmanesh, M.; Shaharudin, M. R.; Chong, Y. S. Green innovation adoption in automotive supply chain: the Malaysian case. J. Clean. Prod. 2015, 108, 1115-1122. [CrossRef]

19. Zhu, Q.; Sarkis, J.; Lai, K. Green supply chain management innovation diffusion and its relationship to organizational improvement: An ecological modernization perspective. J. Eng. Technol. Manag. 2012, 29,168-185. [CrossRef]

20. Govindan, K.; Kaliyan, M.; Kannan, D., Haq, A. N. Barriers analysis for green supply chain management implementation in Indian industries using analytic hierarchy process. Int. J. Prod. Econ. 2014, 147, 555-568. [CrossRef]

21. Min, H.; Kim, I. Green supply chain research: past, present, and future. Logis. Res. 2012, 4, 39-47. [CrossRef]

22. Kannan, D.; de Sousa Jabbour, A. B. L.; Jabbour, C. J. C. Selecting green suppliers based on GSCM practices: Using fuzzy TOPSIS applied to a Brazilian electronics company. Eur. J. Oper. Res. 2014, 233, 432-447. [CrossRef]

23. Tseng, M. L.; Lin, R. J.; Lin, Y. H.; Chen, R. H.; Tan, K. Close-loop or open hierarchical structures in green supply chain management under uncertainty. Expert. Syst. Appl. 2014, 41, 3250-3260. [CrossRef] 
24. Wu, G. C.; Ding, J. H.; Chen, P. S. The effects of GSCM drivers and institutional pressures on GSCM practices in Taiwan's textile and apparel industry. Int. J. Prod. Econ. 2012, 135, 618-636. [CrossRef]

25. Caniato, F.; Caridi, M.; Crippa, L.; Moretto, A. Environmental sustainability in fashion supply chains: An exploratory case based research. Int. J. Prod. Econ. 2012, 135, 659-670. [CrossRef]

26. Sarkis, J.; Zhu, Q.; Lai, K. H. An organizational theoretic review of green supply chain management literature. Int. J. Prod. Econ. 2011, 130, 1-15. [CrossRef]

27. Modi, S. B.; Mabert, V. A. Supplier development: Improving supplier performance through knowledge transfer. J. Oper. Manag., 2007, 25, 42-64. [CrossRef]

28. Vachon, S.; Klassen, R. D. Environmental management and manufacturing performance: The role of collaboration in the supply chain. Int. J. Prod. Econ. 2008, 111, 299-315. [CrossRef]

29. Chin, T. A.; Tat, H. H.; Sulaiman, Z. Green supply chain management, environmental collaboration and sustainability performance. Procedia Cirp. 2015, 26, 695-699. [CrossRef]

30. Flynn, B. B.; Huo, B.; Zhao, X. The impact of supply chain integration on performance: a contingency and configuration approach. J. Oper. Manag. 2010, 28, 58-71. [CrossRef]

31. Barratt, M. Understanding the meaning of collaboration in the supply chain. Supply Chain Manag. Int. J. 2004, 9, 30-42. [CrossRef]

32. Thun, J. H.; Müller, A. An empirical analysis of green supply chain management in the German automotive industry. Expert. Syst. Appl. 2010, 19, 119-132. [CrossRef]

33. Wong, W. P.; Tseng, M. L.; Tan, K. H. A business process management capabilities perspective on organisation performance. Total. Qual. Manag. Bus. 2014, 25, 602-617. [CrossRef]

34. Chen, Y. S.; Lai, S. B.; Wen, C. T. The influence of green innovation performance on corporate advantage in Taiwan. J. Bus. Ethics. 2006, 67, 331-339. [CrossRef]

35. Li, Y. Environmental innovation practices and performance: moderating effect of resource commitment. J. Clean. Prod. 2014, 66, 450-458. [CrossRef]

36. Chen, Y. S.; Chang, C. H.; Lin, Y. H. The determinants of green radical and incremental innovation performance: Green shared vision, green absorptive capacity, and green organizational ambidexterity. Sustainability. 2014, 6, 7787-7806. [CrossRef]

37. Luthra, S.; Garg, D.; Haleem, A. The impacts of critical success factors for implementing green supply chain management towards sustainability: an empirical investigation of Indian automobile industry. $J$. Clean. Prod. 2016, 121, 142-158. [CrossRef]

38. Fraj, E.; Martínez, E.; Matute, J. Green marketing in B2B organisations: an empirical analysis from the natural-resource-based view of the firm. J. Bus. Ind. Mark. 2013, 28, 396-410. [CrossRef]

39. Chen, Y. S. The driver of green innovation and green image-green core competence. J. Bus. Ethics. 2008, 81, 531-543. [CrossRef]

40. Zhao, X.; Huo, B.; Selen, W.; Yeung, J. H. Y. The impact of internal integration and relationship commitment on external integration. J. Oper. Manag. 2011, 29, 17-32. [CrossRef]

41. Swink, M.; Narasimhan, R.; Wang, C. Managing beyond the factory walls: effects of four types of strategic integration on manufacturing plant performance. J. Oper. Manag., 2007, 25, 148-164. [CrossRef]

42. Koufteros, X.; Vonderembse, M.; Jayaram, J. Internal and external integration for product development: the contingency effects of uncertainty, equivocality, and platform strategy. Decision Sciences. 2005, 36, 97-133. [CrossRef]

43. Yang, C. S.; Lu, C. S.; Haider, J. J.; Marlow, P. B. The effect of green supply chain management on green performance and firm competitiveness in the context of container shipping in Taiwan. Transp. Res. E Logist. Transp. Rev. 2013, 55, 55-73. [CrossRef]

44. Zhu, Q., Sarkis, J., Lai, K. H. Institutional-based antecedents and performance outcomes of internal and external green supply chain management practices. J. Purch. Supply. Manag. 2013, 19, 106-117. [CrossRef]

45. Laari, S.; Töyli, J.; Solakivi, T.; Ojala, L. Firm performance and customer-driven green supply chain management. J. Clean. Prod. 2016, 112, 1960-1970. [CrossRef]

46. Huang, Y. C.; Wu, Y. C. The effects of organizational factors on green new product success-evidence from high-tech industries in Taiwan. Management Decision. 2010, 48, 1539-1567. [CrossRef]

47. Roscoe, S.; Cousins, P.; Lamming, R. Developing eco-innovations: a three stage typology of supply networks. J. Clean. Prod. 2016, 112, 1948-1959. [CrossRef]

48. Kong, T.; Feng, T.; Ye, C. Advanced manufacturing technologies, green innovation: the role of internal environmental collaboration. Sustainability. 2016, 8, 1056. [CrossRef] 
49. Paulraj, A.; Jayaraman, V.; Blome, C. Complementarity effect of governance mechanisms on environmental collaboration: does it exist?. Int. J. Prod. Res. 2014, 52, 6989-7006. [CrossRef]

50. Dong, Y.; Wang, X.; Jin, J.; Qiao, Y.; Shi, L. Effects of eco-innovation typology on its performance: Empirical evidence from Chinese enterprises. J. Eng. Technol. Manag. 2014, 34, 78-98. [CrossRef]

51. Patel, P. C.; Azadegan, A.; Ellram, L. M. The effects of strategic and structural supply chain orientation on operational and customer-focused performance. Decision Sciences. 2013, 44, 713-753. [CrossRef]

52. Forsman, H. Environmental innovations as a source of competitive advantage or vice versa?. Expert. Syst. Appl. 2013, 22, 306-320. [CrossRef]

53. Zhu, Q.; Sarkis, J. Relationships between operational practices and performance among early adopters of green supply chain management practices in Chinese manufacturing enterprises. J. Oper. Manag. 2004, 22, 265-289. [CrossRef]

54. Zhu, Q.; Geng, Y.; Lai, K. H. Circular economy practices among Chinese manufacturers varying in environmental-oriented supply chain cooperation and the performance implications. J. Environ. Manag. 2010, 91, 1324-1331. [CrossRef]

55. Cao, M.; Zhang, Q. Supply chain collaboration: Impact on collaborative advantage and firm performance. J. Oper. Manag. 2011, 29, 163-180. [CrossRef]

56. Hair, J. F.; Black, W. C.; Babin, B. J.; Anderson, R. E.; Tatham, R. L. Multivariate data analysis, $7^{\text {th }}$ ed.; Pearson Prentice hall: Upper Saddle River, NJ, USA, 2010. [Google Scholar] 